\title{
THE EFFECT OF LITHIUM ON THE ELECTROCARDIOGRAM OF ANIMALS AND RELATION OF THIS EFFECT TO THE RA- TIO OF THE INTRACELLULAR AND EXTRACELLULAR CONCENTRATIONS OF POTASSIUM
}

\author{
By VICTOR A. McKUSICK ${ }^{1}$
}

\author{
(From the Clinic of General Medicine and Experimental Therapeutics of the National Hcart \\ Institute [Cardiovascular Clinic, U.S.P.H.S. Hospital, Baltimore, Md.] and the De- \\ partment of Medicine, Johns Hopkins University and Hospital, Baltimore, Md.)
}

(Submitted for publication July 16, 1953; accepted December 30, 1953)

The cardiac toxicity of the potassium ion is familiar from observations both in animals and in man. With elevation of the serum potassium a virtually pathognomonic sequence of electrocardiographic changes occurs. Of interest is the effect on the heart of elements from the same periodic group, e.g., lithium, rubidium, and cesium. With the reporting (1-5) of patients with severe untoward reactions from lithium salts taken as a sodium salt substitute, it became of practical significance to evaluate the role of the cardiac toxicity (if any) in the total picture of lithium intoxication. Unexpectedly these studies of the effects of lithium disclosed interesting features of potassium metabolism. Because of ramifications of possible theoretical significance in this connection, a more detailed report than that of four years ago (6) was deemed desirable.

In 1875, Hesse ( 7 ) demonstrated that lithium chloride administered intravenously caused diastolic stoppage of the heart while nerves and muscles were still irritable. Krumhoff $(8,9)$ confirmed this finding in 1884 and made the significant additional observation that much more lithium than potassium is necessary to produce cardiac arrest. From neuromuscular experiments, Milheiro (10) concluded that the effect of lithium is an additive one with potassium.

\section{METHODS}

In acute experiments modeled after those of Winkler, Hoff, and Smith (11) with potassium, lithium chloride, usually in isotonic 0.65 per cent solution, was administered parenterally to six dogs, one cat, two rabbits and six guinea pigs ( $c f$. Table I A, B, C, D). In the case of the guinea pigs the solution of lithium chloride was given by intermittent intraperitoneal injection, whereas in the

\footnotetext{
${ }_{1}$ Present address: The Johns Hopkins Hospital, Baltimore 5, Maryland.
}

three larger species it was given by continuous intravenous infusion. The intravenous solutions were administered at rates which delivered $300 \mathrm{mEq}$. of lithium in a period varying from 15 to 90 minutes in individual experiments. In the guinea pigs $20 \mathrm{cc}$. of isotonic $\mathrm{LiCl}$ solution was administered intraperitoneally at intervals of 15 to 20 minutes. Electrocardiograms were recorded at frequent intervals by means of a Sanborn direct-writing electrocardiograph. In dogs, contact electrodes with conductant jelly were used, whereas in the smaller animals copper wires piercing the limbs and attached to "Fahnstock" clips established contacts with the lead cables. In the case of the dogs, blood samples were taken as the successive electrocardiographic changes developed. In the smaller species, the blood was sampled only at cardiac arrest. All animals were anesthetized at the beginning of the experiments with $65 \mathrm{mg}$. of pentobarbital sodium for each $5 \mathrm{lbs}$. of body weight administered intraperitoneally.

Concentrations of sodium, potassium and lithium in the serum were estimated by means of the Beckman DU Spectrophotometer with flame attachment. In the case of lithium, observations were made at a wave length of 671 millimicrons.

For purposes of estimating lithium and inulin spaces three dogs were subjected to bilateral nephrectomy. Immediately thereafter in two animals $50 \mathrm{cc}$. of 0.65 per cent solution of $\mathrm{LiCl}$ and $10 \mathrm{cc}$. $(1 \mathrm{Gm}$.) of inulin were administered intravenously to each animal. In a third animal only inulin space was determined. The blood was sampled one hour after administration of the inulin and lithium solutions and daily thereafter until death. Water and food were withheld in these animals. Estimations of the concentration of inulin in plasma were made by Harrison's modification (12) of the method of Alving, Rubin, and Miller (13).

The effect of lithium on the loss of potassium from incubated suspensions of human red blood cells was examined in the following manner: suspensions of red cells (as whole blood) were prepared in various proportions of isotonic $\mathrm{LiCl}$ ( 0.65 per cent) solution and of isotonic $\mathrm{NaCl}$ ( 0.85 per cent) solution, as indicated in Figure 6. Each suspension was prepared in triplicate and incubated at $37^{\circ} \mathrm{C}$. for 24 hours. At 1,8 , and 24 hours one of each set of three was removed from incubation and the supernatant analyzed for potassium, sodium, and lithium. 


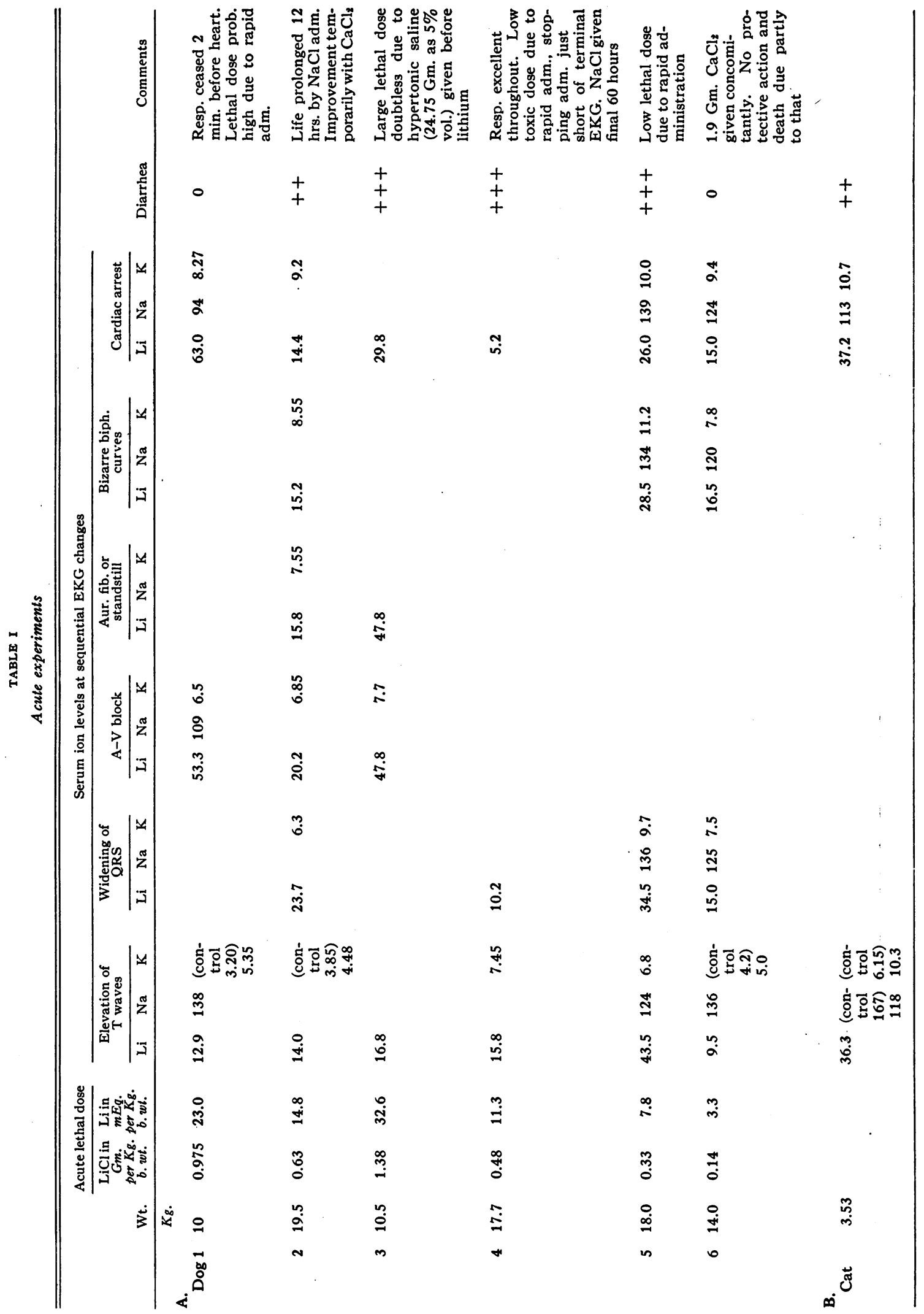




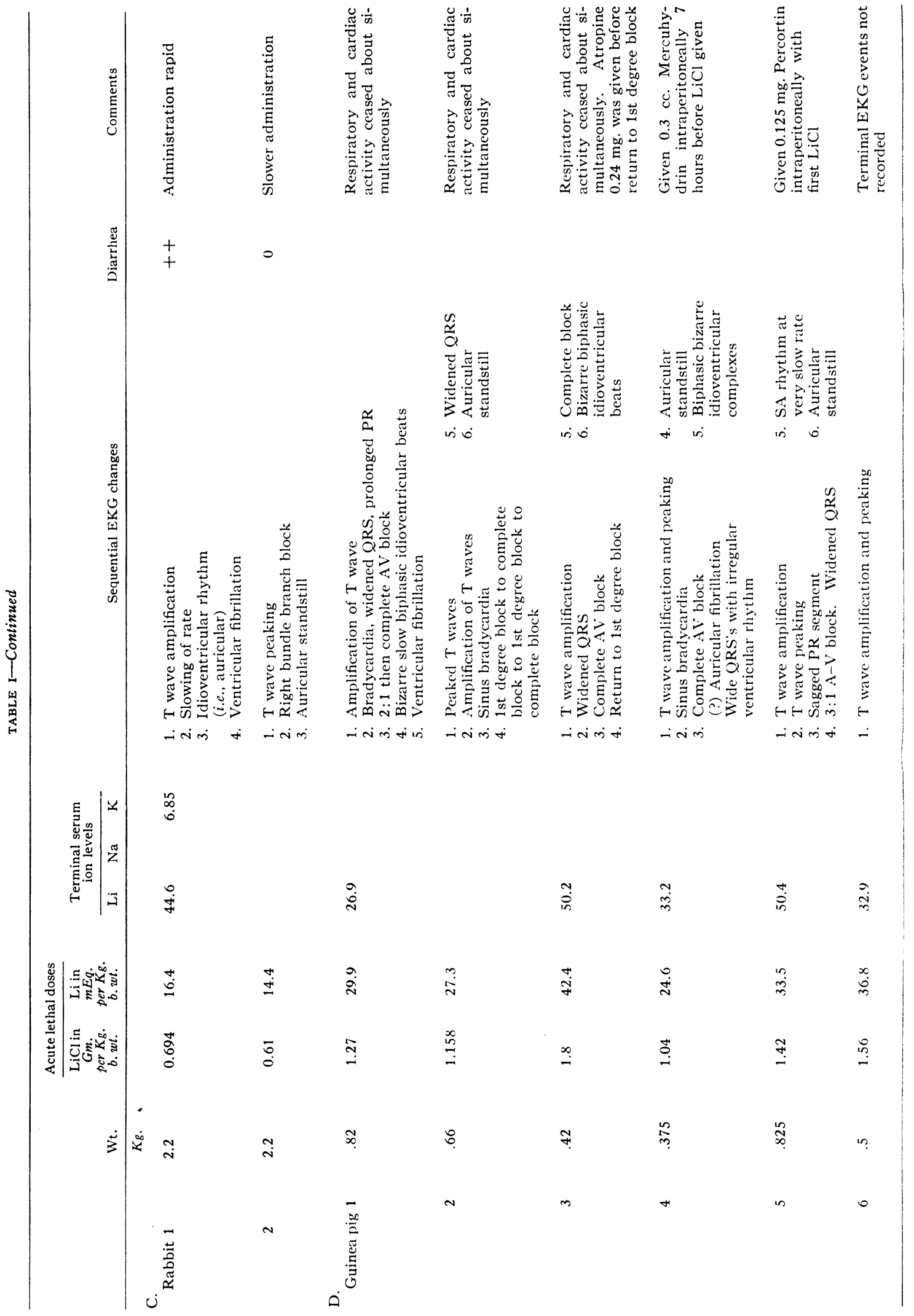




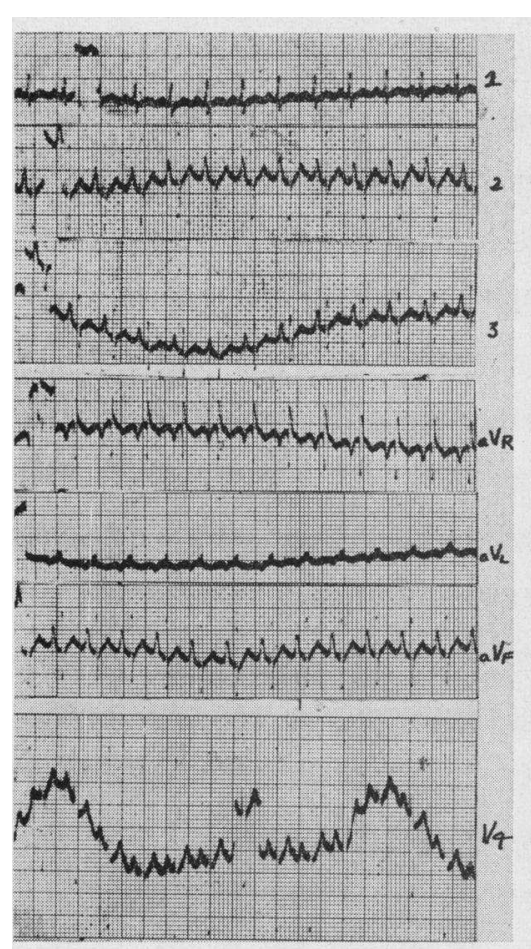

A
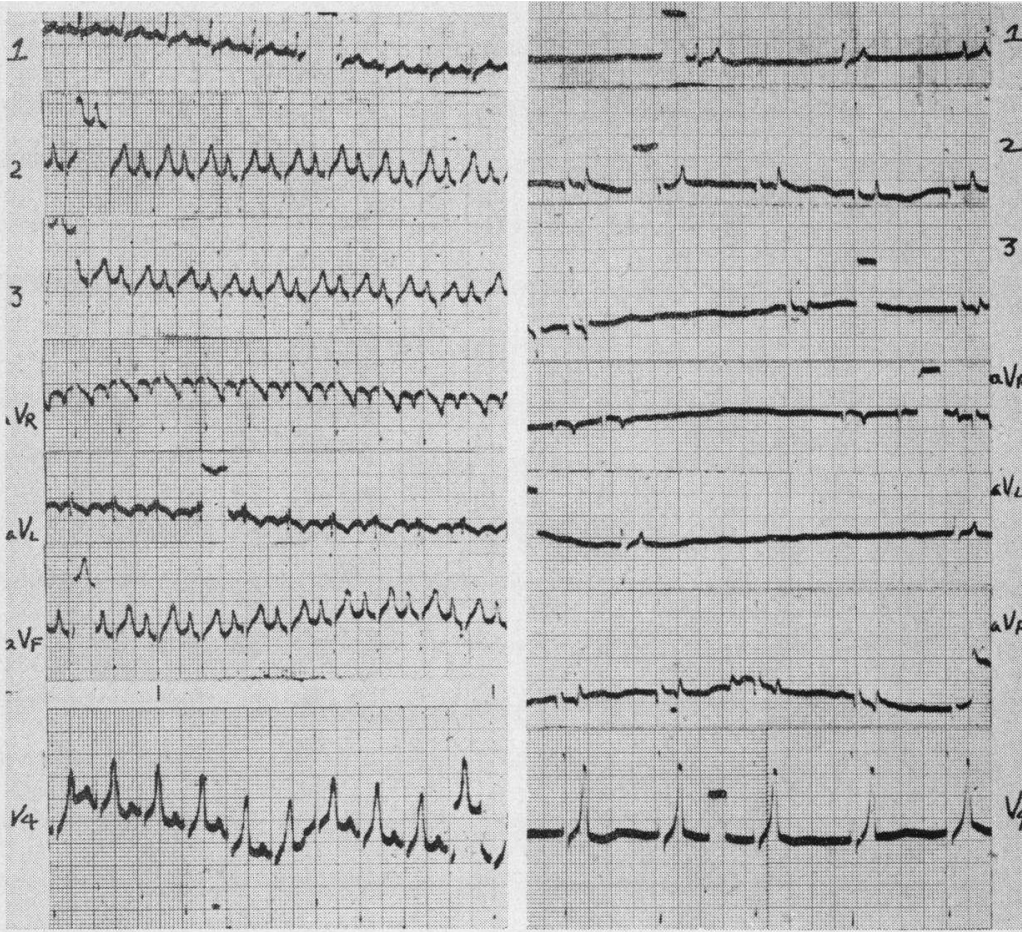

B

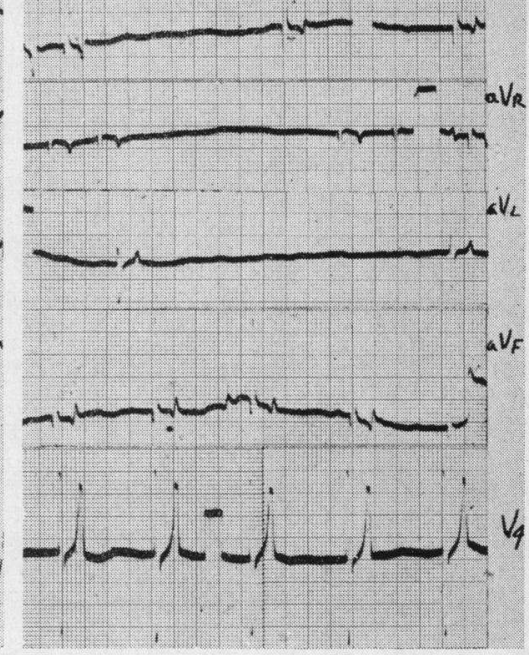

C

Fig. 1. Representative Electrocardiograms-Dog No. 2 of Table IA

A. Control tracings $(2: 30$ p.m.).

B. The first change, peaking of $T$ waves, is demonstrated ( $4: 15$ p.m.).

C. Auricular fibrillation and pronounced slowing of the ventricular rate have developed $(7: 45$ p.m. $)$. The $T$ waves are markedly peaked.

RESULTS

The electrocardiographic effects of acute parenteral lithium administration in animals

A consistent series of electrocardiographic events was observed in all 15 animals of the four species studied (Figures 1 and 2 ). First, the $\mathrm{T}$ waves became high, narrow, and peaked. Secondly, atrial standstill and less frequently atrial fibrillation supervened. First, second, and third degree atrioventricular block was observed in some guinea pigs before the development of the abnormality of atrial mechanism. In two dog experiments intra-atrial electrocardiograms by electrode catheter corroborated the impression of auricular fibrillation followed by atrial standstill at this stage. Thirdly, widening of the QRS appeared and finally there developed a bizarre, biphasic QRS-T pattern at a slow rate, omen of cardiac arrest. The terminal event was ventricular standstill or ventricular fibrillation in about an equal number of animals. At autopsy all of these animals showed dilated hearts suggesting cessation in diastole. (Loud systolic murmurs suggesting cardiac dilatation were heard in the later stages.) In some there were petechial hemorrhages in the myocardium. Both of these changes were described by Krumhoff (8).

Two guinea pigs were given potassium chloride solution in an exactly comparable manner. These animals also showed impairment of $\mathrm{A}-\mathrm{V}$ conduction before the development of atrial standstill or atrial fibrillation, both of which occurred in these animals. In general, the same sequence of changes was seen as has been described for potassium in the dog (11).

The significant finding was that lithium produced the same electrocardiographic sequence as did potassium. Hitherto the series of changes described has been considered unique for hyperkalemia. 
Calcium appeared to antagonize the electrocardiographic effects of lithium to some extent. Sodium was a more effective antagonist. In one dog carried to end-stage changes with lithium, striking improvement, including the return of $\mathrm{P}$ waves, accompanied saline infusion.

\section{DISCUSSION}

The mechanism of the electrocardiographic changes of hyperlithemia

Figures 3, 4, and 5, present charts of three representative dog experiments. In all of the dogs, serum potassium concentration rose steadily in the presence of hyperlithemia, attaining a level of about $10 \mathrm{mEq}$. per liter at the time of cardiac arrest. In one animal (Figure 3) serum potassium concentration continued to rise steadily even after the lithium infusion was discontinued, and the electrocardiogram, rather than improving with the fall

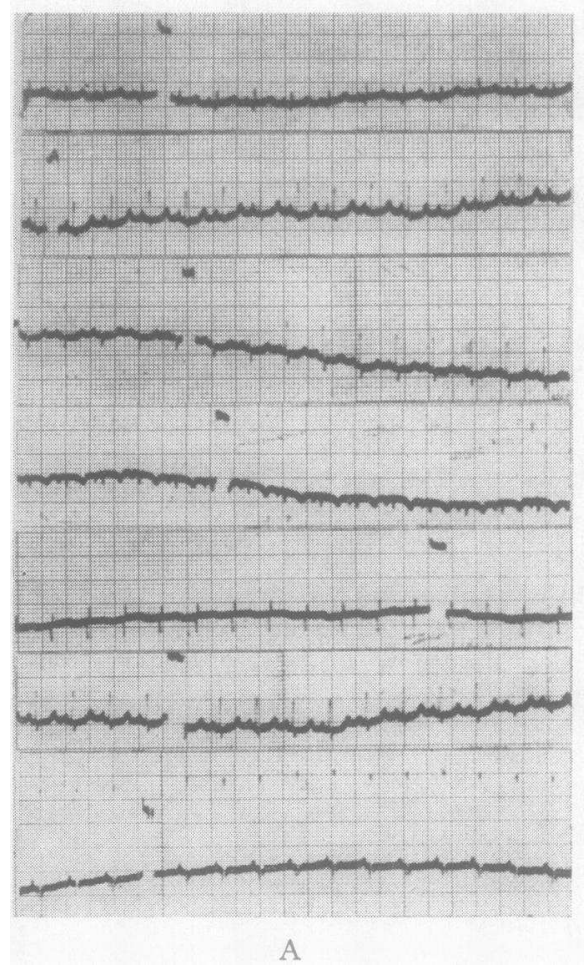

in serum lithium concentration, progressed through the characteristic changes to ventricular standstill. A reciprocal relationship between lithium and sodium concentrations is demonstrated (Figures 4 and 5). (There are suggestions from clinical experience [14] that hyponatremia exaggerates the electrocardiographic effects of hyperkalemia. Such may have been the case to some extent in this situation.) No data was obtained bearing on the question of whether the hyponatremia was the result of dilution, intracellular shift, or natriuresis, or of some combination of these mechanisms.

Inasmuch as the serum lithium concentration bore no direct relationship to the stage of electrocardiographic change observed and since the serum potassium concentration did, it is logical to assume that the electrocardiographic changes are the result of potassium shifts produced by lithium. It is unlikely that renal retention of potassium contributes to the elevation of the serum concentration

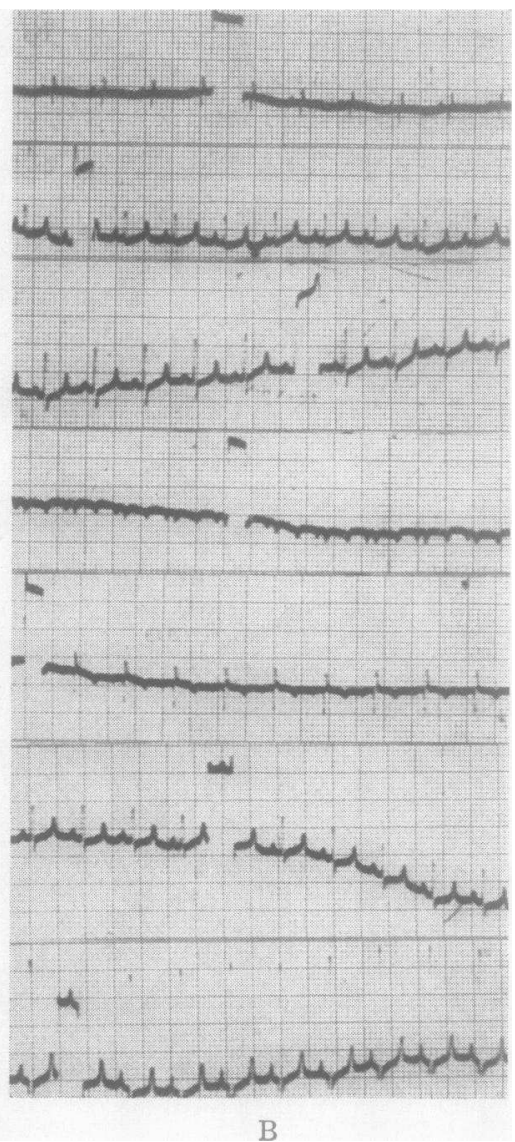

Fig. 2. Representative Electrocardiograms-Guinea Pig No. 5 of Tabie id 


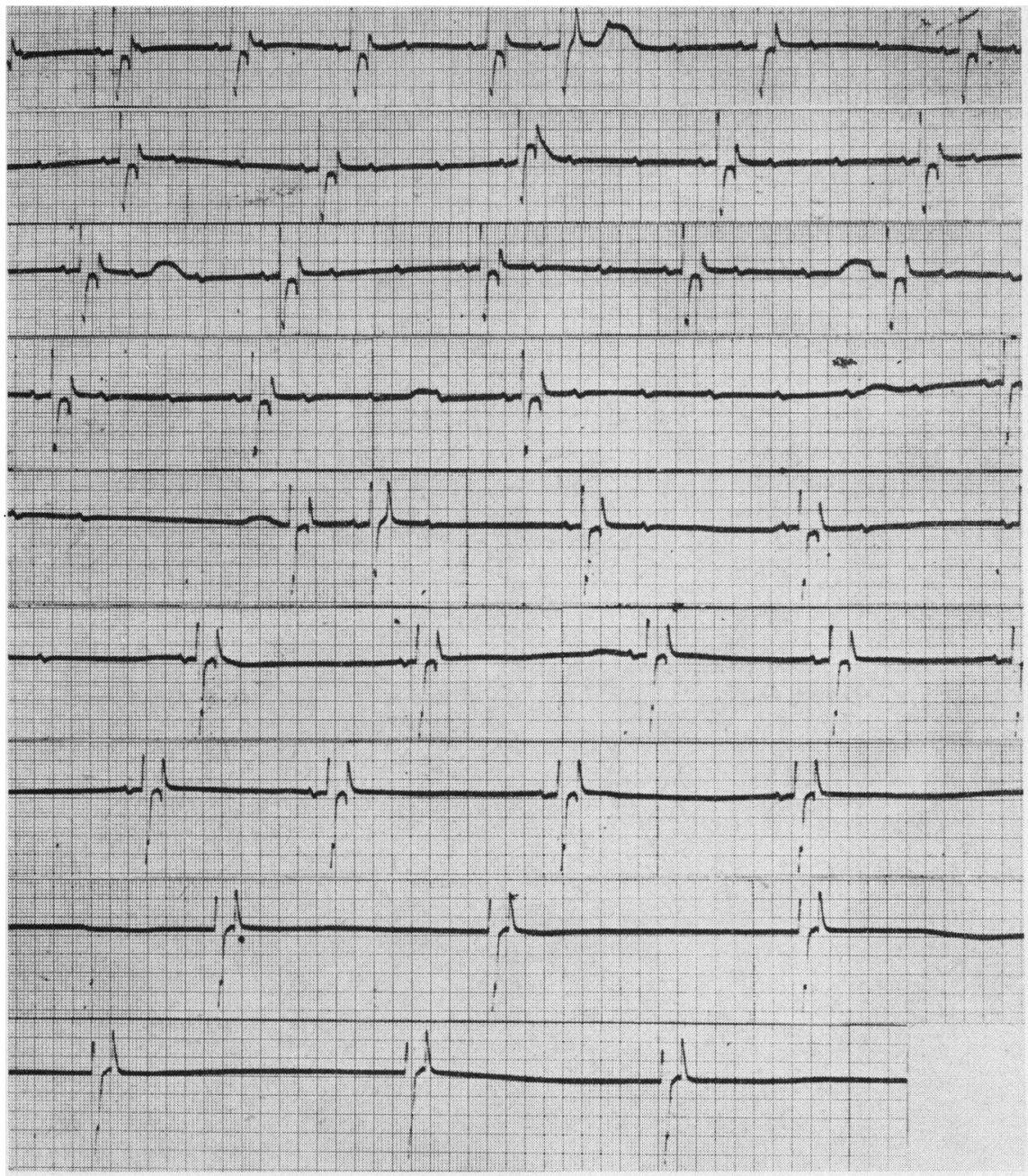

C

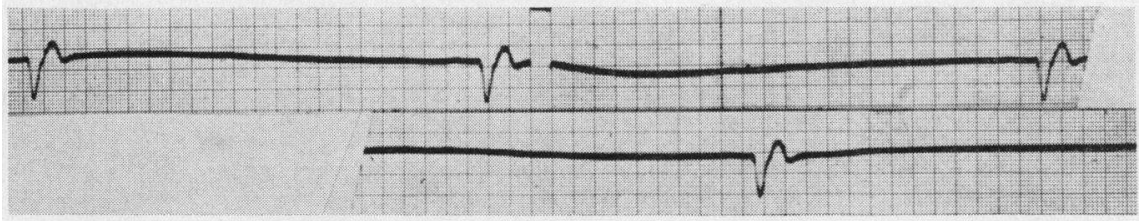

$\mathrm{D}$

Fig. 2. Continued

A. Control tracings $(12: 05$ p.m.).

B. The first change, peaking of $T$ waves, is demonstrated (1:50 p.m.).

C. Various degrees of A-V dissociation developed, followed by auricular standstill (2:35 p.m.). A-V block at this stage is characteristic of both potassium and lithium intoxication in the guinea pig.

D. The terminal idioventricular pattern at a slow rate is demonstrated $(3: 00$ p.m. $)$. 
since the experiments were of only a few hours duration, since urinary output was well maintained until late in each experiment, and since studies of my own and of others (15) reveal an increased renal clearance of potassium when lithium is given. There was little hemolysis in the blood specimens from which the data were accumulated. At any rate, since the red blood cell of all the animals used, except the cat, contains relatively little potassium (16), hemolysis could hardly explain the potassium alteration observed.

The possibilities remain that lithium induces a rise in serum potassium either by displacing the latter ion from the interior of the cell or, less likely, by causing loss of potassium from the cell by indirect means. Both factors may be operative. In-

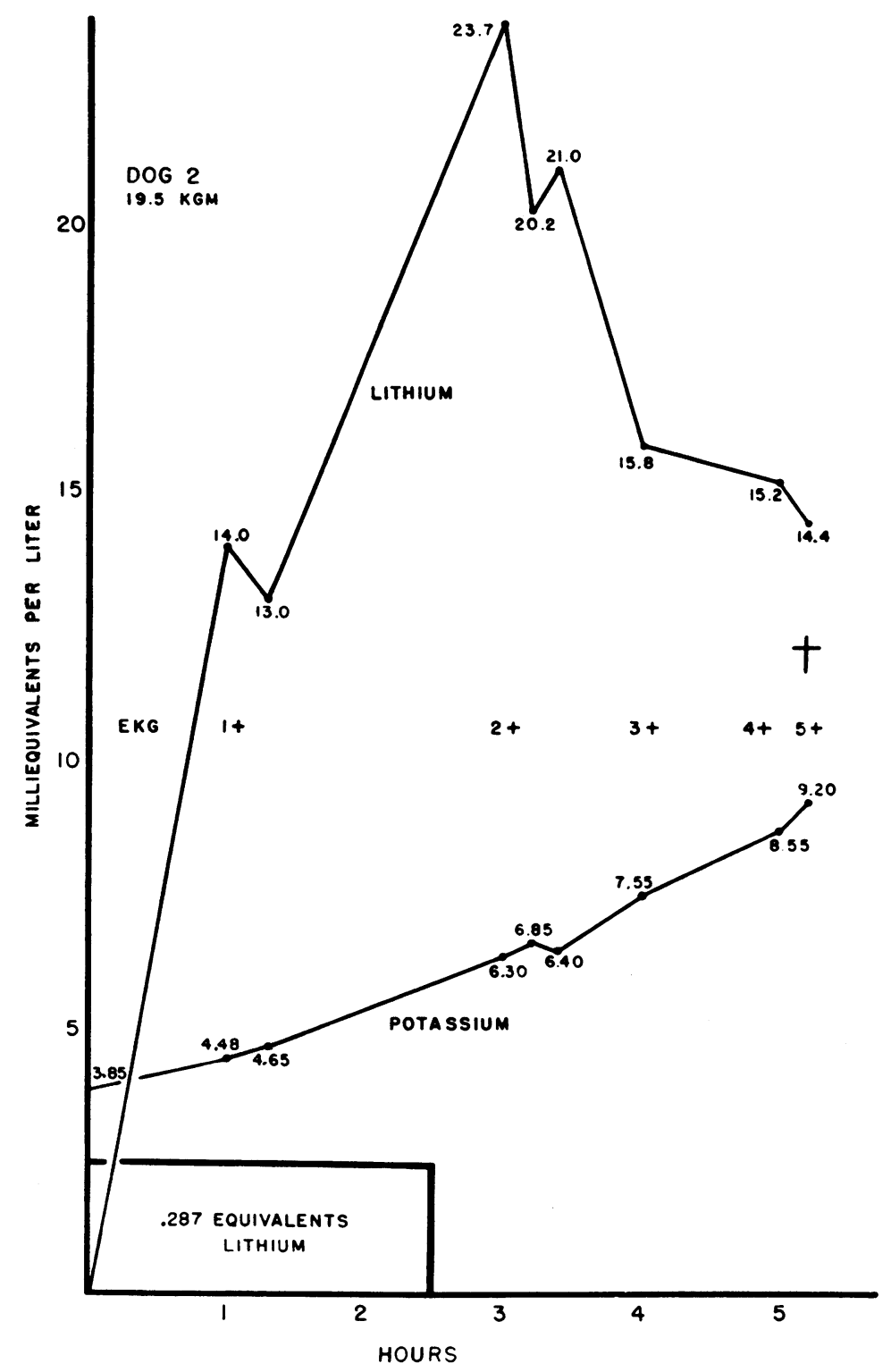

FIGURE 3

Serum potassium concentration continued to rise and electrocardiographic changes to progress in spite of discontinuation of the lithium chloride infusion with resulting fall in serum lithium concentration. Death occurred at the point indicated by the last set of electrolyte determinations. 


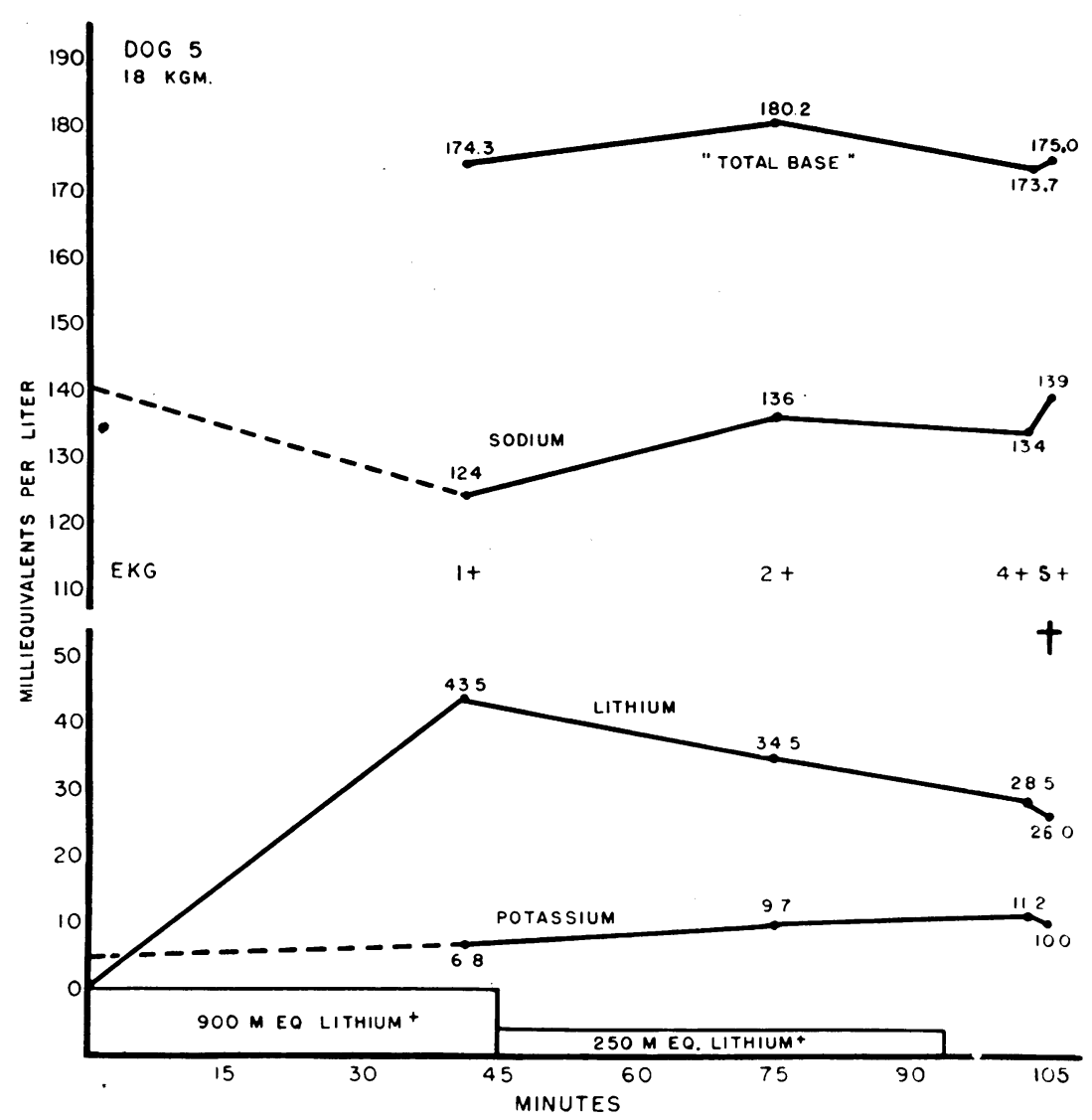

FIGURE 4

This chart also demonstrates the steady progression of potassium rise and electrocardiographic change. It also demonstrates a reciprocal relationship between lithium and sodium. Death occurred at the time indicated by the last set of electrolyte determinations.

tracellular distribution of the lithium ion is supported by comparison of inulin and lithium spaces. The data, dealing with inulin and lithium spaces in nephrectomized dogs, which are presented in Table II indicate that the lithium space always exceeded the inulin space to a significant degree. These data suggest considerable intracellular distribution of the lithium ion. Similar findings have been presented by several groups of workers (15, $17,18)$. The low values for inulin space at one hour probably indicate incomplete distribution in the extracellular compartment. On the other hand, the high values for lithium space on the later days probably reflect extrarenal losses of lithium in stool, saliva, and vomitus. The phenomenon of steadily rising inulin space (Table II) after a single injection of inulin in anuric patients and ncphrectomized dogs was observed by Finkenstaedt, O’Meara, and Merrill (19).

Some of the data from the experiments to test the effect of lithium on the loss of potassium from incubated red blood cells are graphically presented in Figure 6. The potassium concentration of the supernatant at the first hour is indicated as "O" and the increment in potassium concentration thereafter charted. All the suspensions in $\mathrm{LiCl}$ showed greater increments in the potassium concentration of the supernatant than did the suspensions in $\mathrm{NaCl}$ alone. It is impossible to be certain from the sodium concentrations in the supernatant whether the loss of potassium from the red cells represented displacement by one of these ions or not, since there were no significant changes in the concentration of these ions. Ponder (20) was un- 


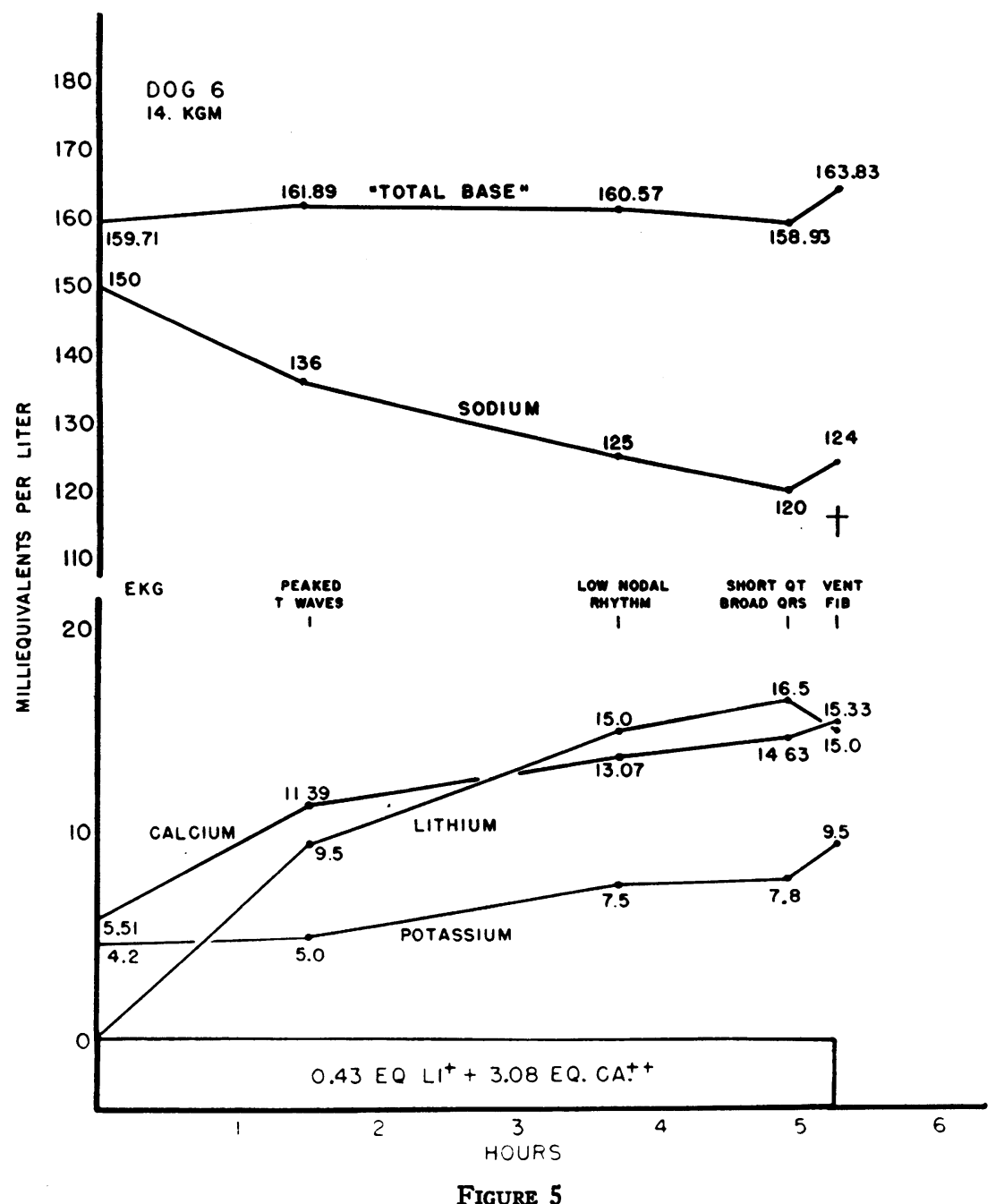

The reciprocal relationship between lithium and sodium is again indicated. Calcium seemed to afford little protection against the effects of lithium on the electrocardiogram and in the amounts used may have contributed to the total toxicity. The last set of electrolyte determinations was derived from blood taken at the time of death.

able to demonstrate any effect of lithium on the loss of potassium from red cells.

Unpublished results of Ling (21) in direct skeletal muscle analyses demonstrate that lithium can displace 90 per cent or more of the potassium from the interior of the cell. Lithium concentration within the muscles rose in direct proportion to the fall in potassium concentration.

Interesting in this connection are the ingenious older experiments of Ödqvist (22) who studied the effect of low concentrations of lithium on the penetrability of potassium for the skin of tadpoles. Also pertinent may be the effects of lithium in low concentrations on aerobic and anaerobic glycolysis (23), inasmuch as normal glycolysis appears to be indispensable for the integrity of the cell membrane, viz., the effects of sodium fluoride (24) and of iodo-acetate (25) which in skeletal muscle produce a gradual fall in resting potential and a loss of potassium from the muscle cell.

The relationship of the physiologic effects of potassium to the ratio of its intracellular and extracellular concentrations

The serum potassium levels at which cardiac arrest occurred in these acute experiments was 3 to 6 
$\mathrm{mEq}$. per liter lower than those which produced cardiac arrest when potassium chloride was infused in acute experiments (11). It is proposed that the cardiac effects of the potassium ion are not a function of its absolute concentration in the extracellular fluid. Instead it may be a function of the ratio of its concentrations within and without the cell $\left(\mathrm{K}^{\mathrm{IC}} / \mathrm{K}^{\mathrm{EC}}\right.$ ) (see Figure 7 ). In the normal situation this ratio is assumed to have a value in the vicinity of 30 . With renal retention of potassium, a situation roughly comparable to that in the infusion experiments may result and the ratio be reduced to about 10 at the extreme with production of characteristic electrocardiographic changes. (Concurrent factors which exaggerate the effects of hyperkalemia, such as hypocalcemia and hyponatremia, are disregarded for the purposes of this exposition.) In hyperlithemia, by reason

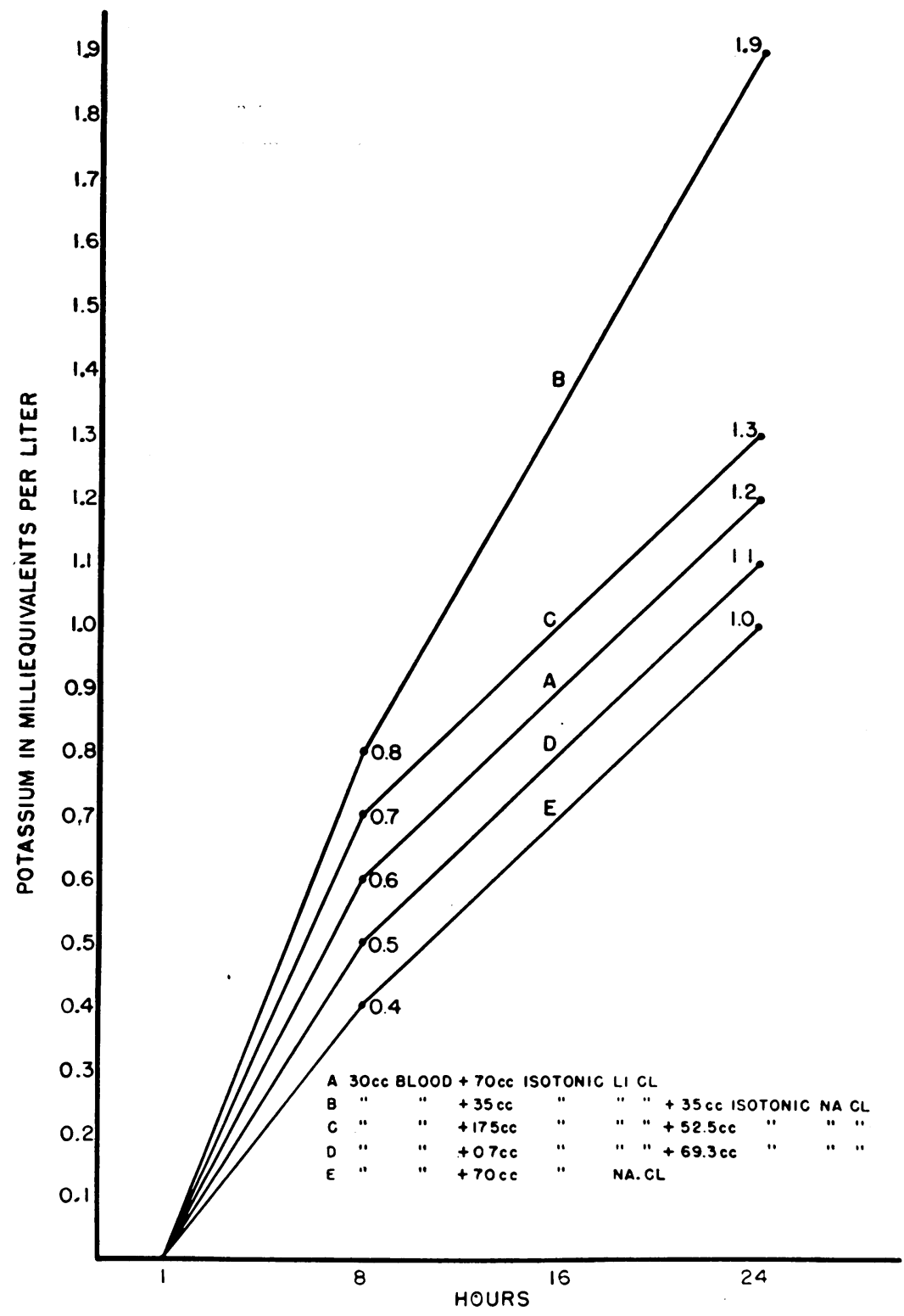

Fig. 6. Effect of Lithium on the Loss of Potassium from the Human Red Blood Cell with Increments in Potassium Concentration of Suspending Media of Various Constitutions (See Text for Details) 
TABLE II

Lithium and inulin spaces in nephrectomized dogs*

\begin{tabular}{|c|c|c|c|c|c|c|}
\hline \multirow{3}{*}{$\frac{\begin{array}{c}\text { Time after } \\
\text { nephrectomy }\end{array}}{1 \text { hour }}$} & \multirow{3}{*}{$\begin{array}{l}\text { Dog } \\
\text { A } \\
\text { B } \\
\text { C }\end{array}$} & \multirow{3}{*}{$\begin{array}{c}\text { Body wt. } \\
K g . \\
19.6 \\
18.6\end{array}$} & \multicolumn{2}{|c|}{ Inulin space } & \multicolumn{2}{|c|}{ Lithium space } \\
\hline & & & Liters & $\%$ body wt. & Liters & $\%$ body $w$ \\
\hline & & & $\begin{array}{l}2.020 \\
2.290\end{array}$ & $\begin{array}{l}10.4 \\
12.3\end{array}$ & $\begin{array}{l}6.700 \\
7.520\end{array}$ & $\begin{array}{l}34.2 \\
40.1\end{array}$ \\
\hline 1 day & $\begin{array}{l}\mathrm{A} \\
\mathrm{B} \\
\mathrm{C}\end{array}$ & $\begin{array}{l}16.8 \\
18.7 \\
17.3\end{array}$ & $\begin{array}{l}2.150 \\
2.840 \\
2.965\end{array}$ & $\begin{array}{l}12.8 \\
15.2 \\
17.1\end{array}$ & $\begin{array}{l}16.450 \\
12.050\end{array}$ & $\begin{array}{l}88.2 \\
69.6\end{array}$ \\
\hline 2 days & $\begin{array}{l}\mathrm{A} \\
\mathrm{B} \\
\mathrm{C}\end{array}$ & $\begin{array}{l}16.4 \\
17.3 \\
16.8\end{array}$ & $\begin{array}{l}3.220 \\
3.270 \\
4.140\end{array}$ & $\begin{array}{l}19.3 \\
18.9 \\
24.8\end{array}$ & $\begin{array}{l}15.340 \\
14.700\end{array}$ & $\begin{array}{l}88.7 \\
87.6\end{array}$ \\
\hline 3 days & $\begin{array}{l}\mathrm{A} \\
\mathrm{B} \\
\mathrm{C}\end{array}$ & $\begin{array}{l}15.4 \\
16.4 \\
16.4\end{array}$ & $\begin{array}{l}3.510 \\
3.710\end{array}$ & $\begin{array}{l}22.8 \\
22.7\end{array}$ & $\begin{array}{l}13.290 \\
14.700\end{array}$ & $\begin{array}{l}81.0 \\
89.7\end{array}$ \\
\hline 4 days & $\stackrel{\mathrm{A}}{\mathrm{C}}$ & $\begin{array}{l}14.5 \\
15.9\end{array}$ & $\begin{array}{l}4.280 \\
4.160\end{array}$ & $\begin{array}{l}29.6 \\
26.2\end{array}$ & 20.250 & 128.7 \\
\hline 5 days & A & 13.6 & 5.215 & 38.3 & & \\
\hline
\end{tabular}

* Dog A. $1 \mathrm{Gm}$. inulin.

Dog B. $1 \mathrm{Gm}$. inulin and $38.4 \mathrm{mEq}$. lithium.

Dog C. $1 \mathrm{Gm}$. inulin and $23.6 \mathrm{mEq}$. lithium.

of a lowering of intracellular potassium concentration, $\mathrm{K}^{\mathrm{IC}} / \mathrm{K}^{\mathrm{EC}}$ may be lowered, roughly to the same value of 10 , and the same electrocardiographic changes produced without as marked an elevation of extracellular potassium.

In diabetic acidosis characteristic hypokalemic electrocardiographic changes may result from elevation of the $\mathrm{K}^{\mathrm{IC}} / \mathrm{K}^{\mathrm{EC}}$ value to 100 , let us say. In

RATIO OF INTRACELLULAR $\mathrm{K}^{+}$TO EXTRACELLULAR $\mathrm{K}^{+}$
\[ \frac{\mathrm{K}^{\mathrm{IC}}}{\mathrm{K}^{\mathrm{EC}}} \]

NORMAL

$$
\frac{150}{5}=30
$$

NORMAL EKG

$\begin{array}{lll}\text { RENAL RETENTION } & \frac{150}{15}=10 & \text { HIGH } K^{+} \text {EKG } \\ \text { HYPERLITHEMIA } & \frac{100}{10}=10 & \text { HIGH } K^{+} \text {EKG } \\ \text { DIABETIC ACIDOSIS } & \frac{120}{1.2}=100 & \text { LOW } k^{+} \text {EKG } \\ \begin{array}{c}\text { FAMILIAL PERIODIC } \\ \text { PARALYSIS }\end{array} & \frac{160}{1.6}=100 & \text { LOW } k^{+} \text {EKG }\end{array}$

Fig. 7. A Theoretical Exposition of the RelationShip of the Ratio of the INTRACEllular and Extracellular Concentrations of Potassium to ElectroCARDIOGRAPHIC FINDINGS familial periodic paralysis, a fall in serum potassium concentration appears to be the result of shift of potassium into cells (26). Because of the resulting increase in the numerator of the ratio, it might be expected that not so marked a fall in serum potassium concentration would be necessary to produce a given physiologic effect. Analysis of reported cases does seem to indicate that such is the case.

The values employed in Figure 7 were selected for illustrative purposes only It is likely that the fall in intracellular potassium concentration with hyperlithemia is much less pronounced than indicated here (27). Assuming that cell water is responsible for 50 per cent of body weight and extracellular water for 20 per cent and assuming that the dog excretes a maximum of 200 micro-equivalents per minute of potassium during lithium administration (15), then the estimated change in intracellular potassium concentration would nòt exceed 10 per cent of the normal value in Dogs 2 . 5 , and 6 reported above.

Several hours may be necessary $(28,29)$ for the restoration of intracellular potassium concentration in a situation of intracellular depletion such as diabetic acidosis or severe diarrhea. Particularly is this true of muscular tissues. Patients have been observed in whom hyperkalemic electrocardio- 
graphic changes developed with lower serum concentrations of potassium than usual when potassium was administered more rapidly than the intracellular restoration could be accomplished. For instance, one patient with diabetic acidosis died of hyperkalemia from the intravenous administration (over a period of a very few minutes) of only 0.9 gram of $\mathrm{KCl}$ from a syringe. Such experiences are explicable on the basis of the physiologic significance of the potassium ratio, or "membrane potassium gradient" as it may be called (30). This concept is essentially that of Bernstein (31) who related muscular excitability and the resting membrane potential to the potassium ratio.

The increase in amplitude of the $T$ wave in spite of presumed reduction in membrane potential may be the result of increased excitability which hyperkalemia produces. Events in all parts of the heart may be transpiring more rapidly and with greater synchronization, to result in a higher but narrower $T$ wave in the case of repolarization. In the case of the QRS complex, explanation for the changes observed is not so simple, it would seem, since frequently widening and amplification of the QRS seem to occur simultaneously.

It is obvious that the above observations in no way exclude the possibility of a more direct action of the lithium ion in the production of the electrocardiographic changes observed.

\section{SUMMARY AND CONCLUSIONS}

1. Elevation of serum lithium concentration is accompanied by a consistent series of electrocardiographic changes indistinguishable from those of hyperkalemia.

2. Lithium causes elevation of serum potassium, probably mainly through direct displacement from the cell.

3. Although direct effects of the lithium ion cannot be excluded on the basis of these data, the electrocardiographic changes of hyperlithemia may be secondary to changes in the ratio of intracellular potassium to extracellular potassium, as may the electrocardiographic changes in other states of altered body potassium concentrations.

\section{ACKNOWLEDGMENTS}

Mr. Alfred Casper and Miss Catharine DeLea assisted in the conduct of these experiments. Dr. Nathan W. Shock gave advice and assistance in performance of part of the electrolyte determinations.

\section{REFERENCES}

1. Salt substitutes-a warning. J. A. M. A., 1949, 139, 588.

2. Corcoran, A. C., Taylor, R. D., and Page, I. H., Lithium poisoning from the use of salt substitutes. J. A. M. A., 1949, 139, 685.

3. Hanlon, F. W., Romaine, M., III, Gilroy, F. J., and Deitrick, J. E., Lithium chloride as a substitute for sodium chloride in the diet. Observations on its toxicity. J. A. M. A., 1949, 139, 688.

4. Stern, R. L., Severe lithium chloride poisoning with complete recovery. Report of case. J. A. M. A., 1949, 139, 710.

5. Waldron, A. M., Lithium intoxication occurring with the use of a table salt substitute in the low sodium dietary treatment of hypertension and congestive heart failure. Univ. Hosp. Bull., Ann Arbor, 1949, $15,9$.

6. McKusick, V. A., Effect of lithium on the electrocardiogram of animals. - Federation Proc., 1950, 9, 84.

7. Hesse, A., Lithion. Inaugural Dissertation Dieterich, Göttingen, 1876. Quoted by Good (9).

8. Krumhoff, E., Experimentelle Beiträge zur Wirkung des Lithium. Inaugural Dissertation, Göttingen, Eisenach, 1884 . Quoted by Good (9).

9. Good, C. A., An experimental study of lithium. Am. J. M. Sc., 1903, n.s., 125, 273.

10. Milheiro, E., Action des associations lithium-potassium et lithium-calcium sur la contracture vératrinique du muscle strié. Compt. rend. Soc. de biol., 1927, 97, 872.

11. Winkler, A. W., Hoff, H. E., and Smith, P. K., Factors affecting the toxicity of potassium. Am. J. Physiol., 1939, 127, 430.

12. Harrison, H. E., A modification of the diphenylamine method for determination of inulin. Proc. Soc. Exper. Biol. \& Med., 1942, 49, 111.

13. Alving, A. S., Rubin, J., and Miller, B. F., A direct colorimetric method for the determination of inulin in blood and urine. J. Biol. Chem., 1939, 127, 609.

14. Finch, C. A., Sawyer, C. G., and Flynn, J. M., Clinical syndrome of potassium intoxication. Am. J. Med., 1946, $1,337$.

15. Foulks, J., Mudge, G. H., and Gilman, A., Renal excretion of cation in the dog during infusion of isotonic solutions of lithium chloride. Am. J. Physiol., 1952, 168, 642.

16. Hoeber, R., Physical Chemistry of Cells and Tissues. Philadelphia, The Blakiston Co., 1945, p. 249.

17. Radomski, J. L., Fuyat, H. N., Nelson, A. A., and Smith, P. K., The toxic effects, excretion and distribution of lithium chloride. J. Pharmacol. \& Exper. Therap., 1950, 100, 429.

18. Davenport, V. D., Distribution of parenterally administered lithium in plasma, brain and muscle of rats. Am. J. Physiol., 1950, 163, 633. 
19. Finkenstaedt, J. T., O'Meara, M. P., and Merrill, J. P., Observations on the volume of distribution of inulin in anuric subjects. J. Clin. Invest., 1953, 32, 209.

20. Ponder, E., The tonicity-volume relations for systems containing human red cells and the chlorides of monovalent cations. J. Gen. Physiol., 1949, 32, 391.

21. Ling, G. N., Personal communication.

22. Ödqvist, G., Permeabilitätsstudien bei kaulguappen. Archiv. för Zoologi., 1925, 17A, No. 30.

23. MacLeod, J., Swan, R. C., and Aitken, G. A., Jr., Lithium: its effect on human spermatozoa, rat testicular tissue and upon rats in vivo. Am. J. Physiol., 1949, 157, 177.

24. Hoeber, R., Loc. cit., p. 250.

25. Ling, G. N., The role of phosphate in the maintenance of the resisting potential and selective ionic accumulation in frog muscle cells in Phosphorus Metabolism, a symposium on the role of phosphorus in the metabolism of plants and animals. W. D.
McElroy and B. Glass, eds., Baltimore, The Johns Hopkins Press, 1952, vol. 2, p. 748.

26. Talbott, J. H., Periodic paralysis; a clinical syndrome. Medicine, 1941, 20, 85.

27. Berliner, R. W., Personal communication.

28. Levitt, M. F., and Gaudino, M., Use of radio-active isotopes to measure intracellular cation concentrations in the normal dog. Am. J. Physiol., 1949, 159, 67.

29. Moore, F. D., Adaptation of supportive therapy to the needs of the surgical patient. J. A. M. A., 1949. $141,646$.

30. Lenzi, F., and Caniggia, A., Intoxication par le chlorure de potassium chez un diabetique en coma: importance du "gradient potassique de surface" sur l'origine des modifications ecg. par $\mathrm{K}^{+}$. Cardiologia, 1951, 19, 265.

31. Bernstein, J., Untersuchungen zur Thermodynamik der bioelektrischen Ströme. Pflüger's Arch. f. d. ges. Physiol., 1902, 92, 521. 